\title{
Ascomycetous yeasts from tropical intertidal dark mud of southeast Brazilian estuaries
}

\author{
Carlos A. G. Soares, ${ }^{1, \dagger}$ Márcio Maury, ${ }^{2}$ Fernando C. Pagnocca, ${ }^{2,+\dagger}$ Fábio V. Araujo, ${ }^{1,2}$ \\ Lêda C. Mendonça-Hagler, ${ }^{2}$ and Allen N. Hagler ${ }^{2, *}$ \\ ${ }^{1}$ Departamento de Ecologia, Instituto de Biologia, Universidade Federal do Rio de Janeiro, Brazil \\ ${ }^{2}$ Instituto de Microbiologia, Universidade Federal do Rio de Janeiro, Brazil
}

(Received June 10, 1997; Accepted October 7, 1997)

\begin{abstract}
Four different intertidal estuarine sediments had distinct yeast communities. One-hundred-ninetythree yeast isolates were classified in 47 species, with 34 of these in the genus Candida. Candida tropicalis was the only ascomycetous species isolated from all four sites. Other opportunistic pathogens including Candida glabrata, Candida guilliermondii, Candida parapsilosis and Candida krusei were present, especially at the more polluted sites. Pichia species were also frequent isolates with Pichia membranaefaciens, and its anamorph, Candida valida, and other phenotypically similar low assimilation profile species the most frequent. Kluyveromyces aestuarii was prevalent at the only site with well established mangrove vegetation, but not present at the other sites. The sediment yeast communities were distinct from each other, but more similar to each other than to the yeast communities of other ecosystems in the same geographic region.
\end{abstract}

Key Words_Candida; Kluyveromyces aestuarii; marine; neotropical; Pichia; sediment; yeasts

Most studies of tropical yeast ecology have focused on terrestrial environments, but aquatic sediments can have relatively high nutrient concentrations and support yeast populations. There have been few studies of the yeast communities of coastal marine ecosystems, and most of these were done in North America (Fell et al., 1960; Fell and van Uden, 1963; Hagler et al., 1982; Lazarus and Korburger, 1974; Meyers and Ahearn, 1974; Meyers et al., 1971; Suehiro, 1963; Volz et al., 1974). Yeasts of coastal sediment habitats may be involved in decomposition, nutrient cycling and in the biotransformation of petroleum, xenobionts and other complex compounds (Ahearn and Meyers, 1972; MacGillivray and Shiaris, 1993; Meyers and Ahearn, 1974).

Yeasts are generally more concentrated in the

\footnotetext{
* Address reprint requests to: Dr. Allen N. Hagler, Departamento de Microbiologia Geral, Instituto de Microbiologia, CCS, Bloco I, Universidade Federal do Rio de Janeiro, Rio de Janeiro, RJ, 21941-590, Brazil.

†Present address: Departamento de Genética, Instituto de Biologia, CCS, Bloco A, Universidade Federal do Rio de Janeiro, Rio de Janeiro, RJ, 21944-970, Brazil.

${ }^{\dagger \dagger}$ Present address: Departamento de Bioquimica e Microbiologia, Instituto de Biosciencias, Universidade Estadual Paulista, Rio Claro, São Paulo, SP, 13,506-900, Brazil.
}

upper layers of aquatic sediments, and the prevalent yeast species are typically found in the water of the same environment. Fermentative yeast species, especially of the Candida krusei-like group (e.g., C. krusei, Candida sorbosa, Pichia kluyveri, Pichia membranaefaciens, its anamorph Candida valida, Pichia terricola, and phenotypically similar yeasts) are prevalent in a heavily polluted subtropical estuary (Hagler et al., 1982). The prevalent basidiomycetous yeasts in fresh and marine waters, Rhodotorula spp. and Cryptococcus spp., are also prevalent in unpolluted estuarine, littoral and deepwater sediments (Fell et al., 1960; Fell and van Uden, 1963; Hagler and Ahearn, 1987; L.azarus and Korburger, 1974; Pagnocca et al., 1989). Some yeasts have been reported to be typical of coastal marine sediments. For example, a large concentration of Kluyveromyces lactis (syn. Kluyveromyces drosophilarum) made up as much as $20 \%$ of the yeast counts in marshland sediments in Louisiana, U.S.A. (Meyers et al., 1971). Pichia spartinae is associated with the oyster grass Spartina alterniflora growing within its culm and predominates in sediment samples from the $S$. alterniflora rhizosphere in these coastal marshlands (Ahearn et al., 1970; Meyers et al., 1970, 1971, 1975). Kluyveromyces aestuarii was isolated from shallow marine sediments of the saltwater but not freshwater of the Everglades in southern 
Florida, U.S.A. (Fell et al., 1960), and was the prevalent yeast of the communities associated with some detritus feeding mangrove invertebrates in southeastern Brazil (Araujo et al., 1995).

Soil and sediments are expected to receive plant, animal and microbial residues from their own and neighboring ecosystems, and these should directly influence the yeast community (Hagler and Ahearn, 1987; Phaff and Starmer, 1987). Estuarine areas are expected to receive both oligotrophic marine waters and freshwater that frequently include sewage from continental environments (Fell and van Uden, 1963; Meyers and Ahearn, 1974; van Uden, 1967). This study reports the differences in the yeast communities of coastal sediments from southeast Brazilian estuaries with different levels of pollution and differences in occurrence of mangrove vegetation.

\section{Materials and Methods}

Sediments were collected from intertidal areas at 4 sampling sites in estuaries of Rio de Janeiro, Brazil: Sites 79 (Coroa Grande mangrove area) and 41 (Pedra de Guaratiba Beach) are located in Sepetiba Bay, and sites 3 (Ilha do Fundão) and 46 (Catalão Point) are located in Guanabara Bay on the Universidade Federal do Rio de Janeiro campus. Site 79 was about $50 \mathrm{~km}$ southwest of the city of Rio de Janeiro, and characterized by dark muddy sediment under mangrove trees (Rhizophora mangle, Avicennia schaueriana and Laguncularia racemosa) in an estuarine complex with freshwater streams originating from the Atlantic Forest (Araujo et al., 1995). Site 41 was located in a muddy intertidal tide flat with no mangrove trees, but $4 \mathrm{~km}$ from the Guaratiba Mangrove Reserve, and with direct influence from an urban area (Pagnocca et al., 1989). Site 46 consisted of a muddy tidal flat characterized by scant recuperating mangrove vegetation on the Ilha do Fundão at Catalão Point, an area several kilometers from any heavily populated urban area but with influences from the Rio de Janeiro urban area and a high amount of solid wastes, especially plastic materials, deposited on the beach. Site 3 was also on Ilha do Fundão, in the channel bordering the mainland and characterized by dark sandy-mud sediment. It had no mangrove vegetation and received raw sewage from a large part of the city of Rio de Janeiro (Hagler et al., 1982).

Samples of 100 to $500 \mathrm{~cm}^{3}$ of sediment were aseptically collected at low tide from the top $5 \mathrm{~cm}$ layer, placed in sterile wide-mouthed glass bottles and returned to the lab on ice within $5 \mathrm{~h}$ for processing. Each sediment sample was mixed with a sterile spatula and subsamples of 50 to $100 \mathrm{~g}$ (wet weight) were diluted in 1 to 2 volumes of sterile $0.85 \% \mathrm{NaCl}$. After 30 s vortex shaking, heavy particles were allowed to settle and aliquots of the supernatant were used for microbial counts and yeast isolation (Hagler et al., 1982). Seawater was also collected at each site and used directly for microbial counts.

Microbial counts were done on 5 or more samples from each site. Total and fecal coliforms (MPN) and heterotrophic bacterial counts (CFU) were done according to standard methods of the American Public Health Association (1990). Yeast and total fungal counts were done by the most probable number method in aquatic yeast broth at $26 \pm 3^{\circ} \mathrm{C}$, and yeast isolations were made on aquatic yeast agar (glucose $1 \%$, $\left(\mathrm{NH}_{4}\right)_{2} \mathrm{SO}_{4} 0.5 \%$, yeast extract $0.5 \%, \mathrm{NaCl} 1 \%$, $\mathrm{NaH}_{2} \mathrm{PO}_{4} 0.2 \%$, agar $1.7 \%$, chloramphenicol $200 \mathrm{mg} / \mathrm{l}$ and $\mathrm{pH} 4.5$ ) spread plates and incubated at $26 \pm 3^{\circ} \mathrm{C}$ (Hagler et al., 1986).

Yeasts were characterized by conventional methods using a multi-tipped inoculation device on solid medium for most of the physiological tests (Kregervan Rij, 1984). Dubious test results were confirmed in individual tubes with broth medium, and the DBB test was done in tubes on YCB-2\% urea agar (Hagler and Mendonça-Hagler, 1991). Identifications followed the keys of Kreger-van Rij (1984) and Barnett et al. (1990). Two or more cultures of the same species from a single sample were considered to be one isolate.

The similarity between the different yeast communities was calculated as the Pearson's product-moment correlation coefficient $(r)$ and clustering was performed using the unweighted pair-group arithmetic averages (UPGMA) procedure (Legendre and Legendre, 1983). Correlations were calculated from the proportional ascomycetous yeast species composition (number of isolates of a species in a specific source/total number of isolates for that source) of each community. Yeast proportions were arcsine square-root transformed before the correlation coefficient calculations.

\section{Results}

Microbial counts in the water and sediment samples are presented in Table 1. Total and fecal coliform counts were highest at site 3 , with individual fecal coliform counts in water ranging from $10^{3}$ to $10^{6} / 100 \mathrm{ml}$. The lowest microbial counts were observed in samples from site 79 , except for the total fungi counts in the water which were lowest at site 41 . Site 79 had about $10^{1}$ fecal coliforms and $10^{2}$ total coliforms/ $100 \mathrm{ml}$ of water, and $10^{2}$ and $10^{3} / 100 \mathrm{~g}$ of sediment. Coliform counts in the water of site 46 were similar to those found for site 79 . Site 41 was intermediate for total and fecal coliform counts but had the highest yeast counts, reaching $10^{2} / 100 \mathrm{ml}$ in water and 
Table 1. Geometric means of microbial counts in water and sediment samples.

\begin{tabular}{|c|c|c|c|c|c|}
\hline \multirow[b]{2}{*}{ Site/sample } & \multicolumn{5}{|c|}{ Microbial counts $^{a}$} \\
\hline & $\begin{array}{c}\text { THB } \\
\text { (CFU) }\end{array}$ & $\begin{array}{c}\mathrm{TC} \\
(\mathrm{MPN})\end{array}$ & $\begin{array}{c}\mathrm{FC} \\
(\mathrm{MPN})\end{array}$ & $\begin{array}{c}\text { TF } \\
(\mathrm{MPN})\end{array}$ & $\begin{array}{c}\text { TY } \\
\text { (MPN) }\end{array}$ \\
\hline Site 79 water & $1.8 \times 10^{5}$ & $2.8 \times 10^{2}$ & $3.9 \times 10^{1}$ & $1.4 \times 10^{3}$ & $3.4 \times 10^{1}$ \\
\hline Site 79 sediment & $8.8 \times 10^{6}$ & $2.2 \times 10^{3}$ & $1.3 \times 10^{2}$ & $4.6 \times 10^{4}$ & $8.1 \times 10^{2}$ \\
\hline Site 41 water & $3.8 \times 10^{6}$ & $2.0 \times 10^{3}$ & $8.7 \times 10^{2}$ & $6.4 \times 10^{2}$ & $3.7 \times 10^{2}$ \\
\hline Site 41 sediment & $4.2 \times 10^{7}$ & $5.1 \times 10^{4}$ & $1.4 \times 10^{4}$ & $6.7 \times 10^{4}$ & $1.4 \times 10^{4}$ \\
\hline Site 46 water & ND & $2.6 \times 10^{2}$ & $7.3 \times 10^{1}$ & ND & ND \\
\hline Site 46 sediment & ND & ND & ND & $1.5 \times 10^{5}$ & $2.5 \times 10^{3}$ \\
\hline Site 3 water & $8.8 \times 10^{6}$ & $4.3 \times 10^{4}$ & $2.7 \times 10^{4}$ & ND & $2.8 \times 10^{2}$ \\
\hline Site 3 sediment & ND & ND & ND & ND & $4.6 \times 10^{3}$ \\
\hline
\end{tabular}

a THB, total heterotrophic bacteria; TC, total coliform bacteria; FC, fecal coliform bacteria; TF, total fungi; TY, total yeasts.

$10^{4} / 100 \mathrm{~g}$ in sediment. Yeast counts were about $10^{1}$ to $10^{2} \mathrm{MPN} / 100 \mathrm{ml}$ in the water samples and from $10^{2}$ to $10^{4} \mathrm{MPN} / 100 \mathrm{~g}$ in the sediment samples. The total fungal counts in all of the sediment samples ranged from $10^{4}$ to $10^{5} / 100 \mathrm{~g}$ and $10^{2}$ to $10^{3} / 100 \mathrm{ml}$ of water. Counts of total heterotrophic bacteria ranged from $10^{6}$ to $10^{7} \mathrm{CFU}$ in the water $(100 \mathrm{ml})$ and sediment $(100 \mathrm{~g})$ samples of all sites.

The mean values for salinity ranged from 21 to $28 \%$ for the interstitial water in sediment samples and from 22 to $26 \%$ for water. Site 79 had the most direct influence from freshwater sources and its salinity varied from 8 to $32 \%$, with the higher values corresponding to higher tide levels at the time of collection. The mean temperatures ranged from 25 to $30^{\circ} \mathrm{C}$ for the sediments and from 25 to $28^{\circ} \mathrm{C}$ for water.

The 192 isolates of ascomycetous yeasts from sediments and the number of isolates from each site are shown in Table 2, with the anamorphic and teleomorphic forms combined into 46 species. Candida was the most frequently isolated genus, with 36 species represented by 164 isolates, and Pichia was the second most frequent, with 19 isolates. Kluyveromyces aestuarii was represented by 17 isolates, making Kluyveromyces a prevalent genus, but it occurred only at site 79 . Basidiomycetous yeasts were generally less frequent than ascomycetes in these communities but more common in the less polluted sites. They were represented by 14 isolates of Rhodotorula spp., 6 isolates of Cryptococcus spp. and 8 isolates of Trichosporon spp., including 4 isolates of Trichosporon cutaneum. The ascomycetous yeast-like organism Geotrichum spp. was represented by 11 isolates from all sites.

Candida tropicalis was frequent at sites 41 and 46, and the only species isolated from all sites. Prevalent species occurring at 3 sites were Candida krusei (especially at sites 41 and 3), Pichia membranaefaciens and its anamorph Candida valida (especially at site 3),
Debaryomyces hansenii and its anamorph Candida famata, Candida glabrata and Candida parapsilosis (mainly at site 41). Candida guilliermondii and Candida intermedia were frequent at site 41 . Forty-one isolates classified in 12 species did not fit the standard description of any species close enough to be considered a possible identification. These isolates were classified to genus level or the closest species and recorded with its name followed by the suffix "-like," whereas a "?" following the name indicates that we feel the fit is close enough to be a possible identification.

The similarities between the ascomycetous yeast communities of sediments from the different sites are presented in Fig. 1 and compared with ascomycetous communities from other habitats of the same region. These included communities from soil of a pineapple plantation (Robbs et al., 1989), from polluted estuarine waters of Sepetiba Bay (Pagnocca et al., 1989) and Guanabara Bay (Hagler and Mendonça-Hagler, 1981), or associated with representative mangrove invertebrates, including the clams Anomalocardia brasiliana and Tagelus plebeius, the shipworm Neoteredo reynei and the crabs Sesarma rectum and Uca sp. (Araujo et al., 1995). Expected outgroup ascomycetous yeast communities of the Brazilian Atlantic Rainforest were represented by yeasts associated with the fruit flies Drosophila melanogaster, $D$. guarani (Morais et al., 1992) and $D$. carolinae groups (Morais et al., 1995). Sediment yeast communities from sites 3,41 and 46 , together with the polluted estuarine water yeast communities from Guanabara Bay and Sepetiba Bay, formed a separate group. Within this group, the sediment yeast community from site 41 in Sepetiba Bay was the closest to that of Sepetiba Bay water, and the heavily polluted sediment community of site 3 in Guanabara Bay was closest to that of the polluted water from Guanabara Bay. The sediment community from the recuperating mangrove area of site 46 in 
Table 2. Frequency of yeast isolates in intertidal dark mud sediments in Rio de Janeiro.

\begin{tabular}{|c|c|c|c|c|c|}
\hline Species & $\begin{array}{l}\text { Site } 79 \\
(n=20)\end{array}$ & $\begin{array}{l}\text { Site } 41 \\
(n=8)\end{array}$ & $\begin{array}{c}\text { Site 46 } \\
(n=3)\end{array}$ & $\begin{array}{l}\text { Site 3 } \\
(n=7)\end{array}$ & $\begin{array}{c}\text { Total } \\
(n=38)\end{array}$ \\
\hline Candida albicans & & & & 2 & 2 \\
\hline Candida apis-like & & & 1 & 6 & 7 \\
\hline Candida atmospherica & & 1 & & & 1 \\
\hline Candida boidinii & 1 & & & 1 & 2 \\
\hline Candida castelli-like & & 3 & & & 3 \\
\hline Candida diddensiae & & 1 & & & 1 \\
\hline Candida famata/Debaryomyces hansenii & & 7 & 2 & 2 & 11 \\
\hline Candida famata-like & 1 & & & & 1 \\
\hline Candida glabrata & 1 & 6 & & 3 & 10 \\
\hline Candida guilliermondii & & 5 & & 1 & 6 \\
\hline Candida guilliermondii-like & 1 & & & & 1 \\
\hline Candida hellenica-like & & 1 & & & 1 \\
\hline Candida holmii & & & & 3 & 3 \\
\hline Candida intermedia & 1 & 6 & & & 7 \\
\hline Candida krissii & & 1 & & & 1 \\
\hline Candida kruisii & & 1 & & & 1 \\
\hline Candida krusei & & 6 & 2 & 7 & 15 \\
\hline Candida lipolytica & & & & 4 & 4 \\
\hline Candida lusitaniae & & 2 & 1 & & 3 \\
\hline Candida maltosa & & 1 & 2 & & 3 \\
\hline Candida nitrativorans & & 1 & 2 & & 3 \\
\hline Candida parapsilosis & & 6 & 1 & 3 & 10 \\
\hline Candida pseudointermedia & & 1 & & & 1 \\
\hline Candida pulcherrima? & & 3 & & & 3 \\
\hline Candida quercuum-like & & 3 & 1 & & 4 \\
\hline Candida silvae & 1 & & & & 1 \\
\hline Candida silvanorum & & 1 & & & 1 \\
\hline Candida sorbosa & & 3 & & 3 & 6 \\
\hline Candida sorbophila & & 1 & & & 1 \\
\hline Candida steatolytica & & & & 2 & 2 \\
\hline Candida terebra & 1 & & & & 1 \\
\hline Candida tropicalis & 1 & 8 & 3 & 3 & 15 \\
\hline Candida utilis & & & & 1 & 1 \\
\hline Candida valida/Pichia membranaefaciens & 2 & 4 & & 7 & 13 \\
\hline Candida valida-like & 2 & & & & 2 \\
\hline Candida spp. & 2 & 8 & 3 & 4 & 17 \\
\hline Kloeckera apiculata & & 1 & & & 1 \\
\hline Kluyveromyces aestuarii & 17 & & & & 17 \\
\hline Metschnikowia sp.? & & & & 1 & 1 \\
\hline Pichia anomala & & 1 & 1 & & 2 \\
\hline Pichia kluyveri & & & & 1 & 1 \\
\hline Pichia terricola & & & & 1 & 1 \\
\hline Pichia spp. & & 2 & & & 2 \\
\hline Saccharomyces cerevisiae & 1 & & & & 1 \\
\hline Schizoblastosporion sp. & 1 & & & & 1 \\
\hline Williopsis saturnus var. subsufficiens & 1 & & & & 1 \\
\hline Total of isolates & 34 & 84 & 19 & 55 & 192 \\
\hline Total of species & 15 & 27 & 11 & 19 & 46 \\
\hline
\end{tabular}

Guanabara Bay was more distant. The less polluted sediment community from the mangrove area of site 79 was closest to typical mangrove invertebrate-associated yeast communities. The yeast community from continental soil (Robbs et al., 1989) had low similarity to the sediment communities and was the most distant from the estuarine communities. The yeast communities of rainforest drosophilids were distant from both those of the estuarine ecosystem and the continental soil.

\section{Discussion}

The salinity variations at site 79 reflect the alternations between continental and marine influences on this estuarine area. Coliform counts show the degree 


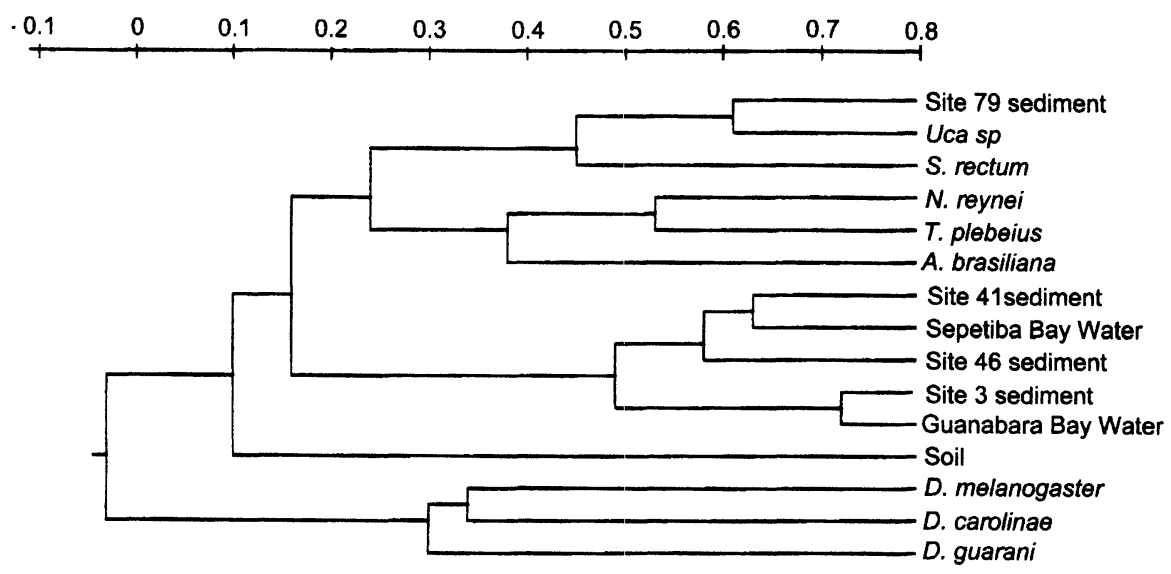

Fig. 1. Dendrogram showing similarities among ascomycetous yeast communities in different sediments noted in Table 2 and other habitats calculated as the Pearson's product-moment correlation coefficient $(r)$ using the UPGMA procedure.

Data on yeast communities for mangrove crabs Uca spp. and Sesarma rectum; and mollusks Tagelus plebeius, Neoteredo reynei and Anomalocardia brasiliana from Araujo et al. (1995), for Sepetiba Bay water (site 41) from Pagnocca et al. (1989); for Guanabara Bay water (site 3) from Hagler and Mendonça-Hagler (1981); for pineapple plantation soil from Robbs et al. (1989); and for tropical rainforest fruit flies Drosophila melanogaster, Drosophila carolinae and Drosophila guarani from Morais et al. (1992, 1995).

of recent fecal pollution, with site 3 having the highest and site 79 the lowest levels. Site 46 is far from any point source of sewage, but was subject to less recent contamination since it is situated in Guanabara Bay, which is known to be severely affected by sewage (Araujo et al., 1990, 1991; Kosawa da Costa et al., 1991). The heterotrophic bacteria, total fungi and total yeast counts show the ability of these substrates to support a dense heterotrophic microbial community. All microbial counts were 10 to 100 -fold higher in the sediments than in the water of the respective sites, probably reflecting higher nutrient levels in the sediments.

Candida and Pichia were the most frequently isolated genera from sediments of Rio de Janeiro, and are also frequently isolated from forest and aquatic environments including some mangrove substrates (Araujo et al., 1995; Hagler and Ahearn, 1987; Hagler et al., 1993; Morais et al., 1992, 1995). The opportunistic pathogens $C$. glabrata, C. guilliermondii, $C$. krusei, $C$. parapsilosis and $C$. tropicalis were prevalent at the polluted sites, as were $P$. membranaefaciens and $C$. intermedia, all of which have been linked to polluted environments and sewage (Ahearn et al., 1968; Buck et al., 1977; Hagler and Ahearn, 1987; Hagler et al., 1982; Hurley et al., 1987; Meyers and Ahearn, 1974). The frequent isolation of C. glabrata and the occurrence of some isolates of the pathogen C. albicans were consistent with the presence of fecal contamination possibly from human or animal sources including mammals and birds typical of mangroves and estuaries (Hutchings and Saenger, 1987). C. glabrata appeared in relatively unpolluted sediments, suggest- ing it is well adapted to marine sediment conditions. The occurrence of Trichosporon spp., especially T. cutaneum, could also be from pollution influences. But this group has been found in substrates like wood, soil, beach sand and seawater (Hurley et al., 1987). The species $D$. hansenii (and its anamorph $C$. famata) is common in terrestrial habitats. But it is also the most frequent ascomycete in clean and polluted seawater environments and is associated with plants and animals (Ahearn et al., 1968; Hagler and Ahearn, 1987; Hagler and Mendonça-Hagler, 1981; Meyers and Ahearn, 1974; Pagnocca et al., 1989; van Uden, 1967). This species presents many variable physiological features, making it easy for an undescribed species to fit within its standard description. In such a case, this yeast could be less of a generalist than it now appears to be in ecological studies because of a high possibility for misidentification. Ascomycetous yeasts with characteristic low assimilation profiles were frequently isolated from sediments. Many of these yeasts fit the descriptions of $C$. krusei, C. sorbosa or $P$. membranaefaciens, but there were also many strains with intermediate physiological profiles. The relatively high sugar concentrations of the culture medium and short incubation periods at about $26^{\circ} \mathrm{C}$, rather than lower temperatures, should not have favored isolation of basidiomycetous yeasts because isolation plates were often overgrown by molds before they could be isolated. However, Rhodotorula and Cryptococcus were frequently observed in aquatic environments, and we obtained some isolates, especially from the less polluted sites, which may have favored their oxidative metabolisms (Hagler and 
Ahearn, 1987; Hagler et al., 1982). The weakly fermentative yeast-like Geotrichum spp. isolates represent the occurrence of a group of cosmopolitan yeasts included in polluted aquatic environments, soils, plants and insects (Hagler and Ahearn, 1987; Morais et al., 1992, 1995; Phaff and Starmer, 1987; Robbs et al., 1989; Rosa et al., 1992, 1994, 1995; Starmer et al., 1990).

Kluyveromyces aestuarii was isolated frequently from the mangrove area at site 79 , but not from other sites. This species was first isolated from estuarine sediments in Florida, U.S.A. (Fell, 1961; Fell et al., 1960 ), and its occurrence seems to be related more specifically to sediment and detritus feeding organisms in mangrove ecosystems. We found $K$. aestuarii to be the prevalent yeast associated with some mangrove invertebrates, but not occurring in yeast communities from invertebrates living near the mangrove stands or those in mangroves that do not feed on detritus (Araujo et al., 1995). The presence of a small recovering mangrove stand at site 46 apparently was not enough to promote the occurrence of $K$. aestuarii. It would be of interest to monitor this site and see if and when the species appears as the mangrove reestablishes. Site 41 , with dark mud having the appearance of mangrove sediment and only $4 \mathrm{~km}$ from a large mangrove reserve area, was also free of $K$. aestuarii. Ahearn et al. (1968) also frequently isolated $K$. aestuarii from the Everglades in Florida, U.S.A., but only from a brackish water area with mangrove vegetation. It is still not clear if $K$. aestuarii is a stable component of the mangrove yeast community or occurs in occasional blooms or as part of a succession. The colonies of this yeast are white to cream in color initially but often turn pink-brown with age as ascospores are formed. Most cultures sporulate forming 1 to 4 round ascospores per ascus, but these often do not dehisce as readily as in other Kluyveromyces species. The physiological profiles of $K$. aestuarii isolates from sediments and mangrove invertebrates (Araujo et al., 1995) were in good agreement with the standard description by Barnett et al. (1990) and Kreger van Rij (1984), but there was positive assimilation of L-sorbose for 38 of the 45 isolates and of D-xylose for 2 isolates. However, these do not represent new biotypes since these abilities were noted in the original description of the species and may have been lost in the collection cultures (Fell, 1961). Molecular, physiological, morphological and nDNA/nDNA hybridization studies indicate that the mangrove yeast $K$. aestuarii and the marshland yeast $K$. lactis are similar species that are related to K. marxianus (Herman, 1970; Kilian et al., 1991; Lachance, 1989; Martini et al., 1972; Shen et al., 1994). K. marxianus is commonly isolated from temperate and tropical forest drosophilids which should act as vectors for the species among its microhabitats (Morais et al., 1992, 1995; Phaff and Starmer, 1987). This phylogeny may be the consequence of an evolutionary shift to marine environments from a common terrestrial ancestor. The phylogenetic distance between $K$. aestuarii and $K$. marxianus has been interpreted as an indication of genetic isolation (Johannsen, 1980) and may have resulted from the occupation of distinct habitats.

The sediment yeast community from site 79 showed a close similarity to those from other typical mangrove substrates (Fig. 1). Although being close to a mangrove preservation area and having fine dark sediment, the sediment yeast community at site 41 did not have much similarity with the mangrove communities. It was more similar to that in the water of site 41 , with mostly cosmopolitan yeasts typical of polluted waters and terrestrial habitats. The yeast community from the most polluted area at site 3 was similar to that of polluted water from the same region in Guanabara Bay. The more polluted habitats appeared to be dominated more by allochthonous species and less distinct from other yeast communities. The recovering mangrove area yeast community at site 46 was apparently not yet differentiated as a mangrove sediment community, and although receiving some influence from Guanabara Bay pollutants, was not as strongly associated with yeasts of domestic pollution as the sediment community of site 3 on the other side of the same island. The estuarine sediment yeast communities were not closely related to that of a sandy continental soil of a pineapple plantation, which was dominated mainly by basidiomycetous yeasts (Robbs et al., 1989), although the difference in isolation methods may be partially responsible for the difference. The yeast communities from rainforest drosophilids, representing a yeast community from a geographically adjacent ecosystem, appeared as outgroups in relation to those of intertidal sediment and water, showing them to be distinct.

We thank Renato F. de Oliveira and Jose Olavo de Nascimento for their dedicated field and laboratory assistance, Pedro R. Peres Neto for help with the statistical analysis, David Yarrow for sending type and authentic cultures, and J. W. Fell and an anonymous reviewer for constructive comments and criticism. This work was supported by Conselho Nacional de Desenvolvimento Científico e Tecnológico (CNPq) and Financiadora de Estudos e Projetos (FINEP) and the European Community International Scientific Cooperation Program (DG-XII) research contract to A. Martini and L. C. Mendonça-Hagler.

\section{References}

Ahearn, D. G. and Meyers, S. P. (1972) The role of fungi in the decomposition of hydrocarbons in the marine environment. In Biodeterioration of Materials, Vol. 2, ed. by Harry Walters, A. and Hueck-van der Plas, E. H., Applied Science, London. 
Ahearn, D. G., Roth, F. J., and Meyers, S. P. (1968) Ecology and characterization of yeasts from aquatic regions of South Florida. Mar. Biol., 1, 291-308.

Ahearn, D. G., Yarrow, D., and Meyers, S. P. (1970) Pichia spartinae sp. n. from Louisiana marshland habitats. Antonie Leeuwenhoek, 36, 503-508.

American Public Health Association (1990) Standard Methods for the Examination of Water and Wastewater, 16th ed., American Public Health Assoc., New York.

Araujo, F. V., Soares, C. A. G., Hagler, A. N., and Mendonça-Hagler, L. C. (1995) Ascomycetous yeast communities of marine invertebrates in a Southeast Brazilian mangrove ecosystem. Antonie Leeuwenhoek, 68, 91-99.

Araujo, F. V., van Weerelt, M., Franco, G. M. O., Soares, C. A. G., Hagler, A. N., and Mendonça-Hagler, L. C. (1991) Microbial levels of coastal waters of Rio de Janeiro (RJ, Brazil). In Coastal Zone 91, Vol. 4, ed. by Magoon, O. T., Converse, H., Tippie, V., Tobin, L. T., and Clark, D., pp. 3246-3258.

Araujo, M. A., Guimarães, V. F., Mendonça-Hagler, L. C., and Hagler, A. N. (1990) Staphylococcus aureus and fecal streptococci in fresh and marine surface waters of Rio de Janeiro, Brazil. Rev. Microbiol., 21, 141-147.

Barnett, J. A., Payne, R. W., and Yarrow, D. (1990) Yeasts: Characteristics and Identification, 2nd ed., Cambridge University Press, Cambridge, $1002 \mathrm{pp}$.

Buck, J. D., Bubucis, P. M., and Combs, T. J. (1977) Occurrence of human associated yeasts in bivalve shellfish from Long Island Sound. Appl. Environ. Microbiol., 33, 370-378.

Fell, J. W. (1961) A new species of Saccharomyces isolated from a subtropical estuary. Antonie Leeuwenhoek, 27, 27-30.

Fell, J. W., Ahearn, D. G., Meyers, S. P., and Roth, E. J., Jr. (1960) Isolation of yeasts from Biscayne Bay, Florida and adjacent benthic areas. Limnol. Oceanogr., 5, 366-371.

Fell, J. and van Uden, N. (1963) Yeasts in marine environments. In Symposium on Marine Microbiology, ed. by Oppenhein, C. H., Charles Thomas, Springfield, pp. 329-340.

Hagler, A. N. and Ahearn, D. G. (1987) Ecology of aquatic yeasts. In The Yeasts, 2nd ed., Vol. 1, ed. by Rose, A. H. and Harrison, J. S., Academic Press, London, pp. 181-205.

Hagler, A. N. and Mendonça-Hagler, L. C. (1981) Yeasts from marine and estuarine water with different levels of pollution in the State of Rio de Janeiro, Brazil. Appl. Environ. Microbiol., 41, 173-178.

Hagler, A. N. and Mendonça-Hagler, L. C. (1991) A Diazonium Blue $B$ test for yeasts grown three days on Yeast Carbon Base-Urea Agar. Rev. Microbiol. São Paulo, 22, 71-74.

Hagler, A. N., Mendonça-Hagler, L. C., Silva, J. B. F., Santos, E. A., Farage, S., Shrank, A., and de Oliveira, R. B. (1986) Evaluation of microbial pollution indicators in Brazilian tropical and subtropical marine surface waters. Sci. Total Environ., 58, 151160.

Hagler, A. N., Oliveira, R. B., and Mendonça-Hagler, L. C. (1982) Yeasts in the intertidal sediments of a polluted estuary in Rio de Janeiro, Brazil. Antonie Leeuwenhoek, 48, 53-56.

Hagler, A. N., Rosa, C. A., Morais, P. B., Mendonça-Hagler, L. C., Franco, G. M. O., Araujo, F. V., and Soares, C. A. G. (1993) Yeasts and coliform bacteria of water accumulated in bromeliads of mangrove and sand dune ecosystems of Southeast Brazil. Can. J. Microbiol., 39, 973-981.

Herman, A. I. (1970) Interspecies sex-specific growth responses in Kluyveromyces. Antonie Leeuwenhoek, 36, 421-425.

Hurley, R., Louvois, J. de, and Mulhall, A. (1987) Yeasts as human and animal pathogens. In The Yeasts, 2nd ed., ed. by Rose, A. H. and Harrison, J. S., Academic Press, London, pp. 207-281.

Hutchings, P. and Saenger, P. (1987) Ecology of Mangroves, Univ. Queensland Press, $388 \mathrm{pp}$.
Johannsen, E. (1980) Hybridization studies within the genus Kluyveromyces van der Walt emend. van der Walt. Antonie Leeuwenhoek, 46, 177-189.

Kilian, S. G., vanDeemter, A., Kock, J. L. K., and du Preez, J. C. (1991) Occurrence and taxonomic aspects of proton movements coupled to sugar transport in the yeast genus Kluyveromyces. Antonie Leeuwenhoek, 59, 199-206.

Kosawa da Costa, A. M., Sanches Nunes, M. L., van Weerelt, M. D. M., Fonseca Faria, G. V., Mendonça-Hagler, L. C., and Hagler, A. N. (1991) Microbial quality of the mussel Perna perna extracted from Guanabara Bay (RJ, Brazil). In Coastal Zone 91, Vol. 4, ed. by Magoon, O. T., Converse, H., Tippie, V., Tobin, L. T., and Clark, D., pp. 3259-3267.

Kreger-van Rij, N. J. W. (1984) The Yeasts: A Taxonomic Study, 3rd ed., Elsevier Science Publ. B. V., Amsterdam, $1082 \mathrm{pp}$.

Lachance, M. A. (1989) Restriction mapping of rDNA and the taxonomy of Kluyveromyces van der Walt emend. van der Walt. Yeast, 5, S379-S383.

L.azarus, C. R. and Korburger, J. A. (1974) Identification of yeasts from the Suwannee River Florida Estuary. Appl. Microbiol., 27, 1108-1111.

L.egendre, L. and Legendre, P. (1983) Numerical Ecology, Elsevier, New York, $419 \mathrm{pp}$.

MacGillivray, A. R. and Shiaris, M. P. (1993) Biotransformations of polycyclic aromatic hydrocarbons by yeasts isolated from coastal sediments. Appl. Environ. Microbiol., 59, 1613-1618.

Martini, A., Phaff, H. J., and Douglas, S. A. (1972) Deoxyribonucleic acid base composition of species in the yeast genus Kluyveromyces van der Walt emend. van der Walt. J. Bacteriol., 111, 481-487.

Meyers, S. P. and Ahearn, D. G. (1974) Implication of yeasts and yeast like fungus in marine processes. Veroeff. Inst. Meeresforsch. Bremerhaven Suppl., 5, 321-338.

Meyers, S. P., Ahearn, D. G., Alexander, S. K., and Cook, W. L. (1975) Pichia spartinae, a dominant yeast of the Spartina salt marsh. Dev. Ind. Microbiol., 6, 261-267.

Meyers, S. P., Ahearn, D. G., and Miles, P. (1971) Characterization of yeasts in Baratara Bay. La. St. Univ. Coastal Stud. Bull., 6, $7-15$.

Meyers, S. P., Nicholson, M. L., Rhee, J., Miles, P., and Ahearn, D. G. (1970) Mycological studies in Baratara Bay, Louisiana and biodegradation of oyster grass, Spartina alterniflora. Coastal Studies Bulletin n ${ }^{\circ}$ /Special Sea Grant Issue, pp. 111-124.

Morais, P. B., Hagler, A. N., Rosa, C. A., Mendonça-Hagler, L. C., and Klaczcko, L. B. (1992) Yeasts associated with Drosophila in tropical forests of Rio de Janeiro, Brazil. Can. J. Microbiol., 38, 1150-1155.

Morais, P. B., Rosa, C. A., Hagler, A. N., and Mendonça-Hagler, L. C. (1995) Yeast communities as descriptors of habitat use by the Drosophila fasciola subgroup (repleta group) in Atlantic Rain Forest. Oecologia, 104, 45-51.

Pagnocca, F. C., Mendonça-Hagler, L. C., and Hagler, A. N. (1989) Yeasts associated with the white shrimp Penaeus schmitti, sediment and water of Sepetiba Bay, Rio de Janeiro, Brazil. Yeast, 5, S479-S483.

Phaff, H. J. and Starmer, W. T. (1987) Yeasts associated with plants, insects and soils. In The Yeasts, 2nd ed., Vol. 1, ed. by Rose, A. H. and Harrison, J. S., Academic Press, New York, pp. 123-180.

Robbs, P. G., Hagler, A. N., and Mendonça-Hagler, L. C. (1989) Yeasts associated with a pineapple plantation in Rio de Janeiro, Brazil. Yeast, 5, S485-S489.

Rosa, C. A., Hagler, A. N., Mendonça-Hagler, L. C., Morais, P. B., Gomes, N. M. C., and Monteiro, R. F. (1992) Clavispora opuntiae and other yeasts associated with the moth Sigelgaita sp. in the cactus Pilosocereus arrabidae of Rio de Janeiro, Brazil. An- 
tonie Leeuwenhoek, 62, 267-272.

Rosa, C. A., Morais, P. B., Mendonça-Hagler, L. C., Monteiro, R., and Hagler, A. N. (1994) Yeast communities of the cactus Pilosocereus arrabidae and associated insects in the sandy coastal plains of Southeastern Brazil. Antonie Leeuwenhoek, $65,55-62$.

Rosa, C. A., Morais, P. B., Santos, S. R., Peres Neto, P. R., Mendonça-Hagler, L. C., and Hagler, A. N. (1995) Yeasts communities associated with different plant habitats in sandy coastal plains in Brazil. Mycol. Res., 99, 1047-1054.

Shen, P., Jong, S. C., and Molina, F. I. (1994) Analysis of ribosomal DNA restriction patterns in the genus Kluyveromyces. Antonie Leeuwenhoek, 65, 99-105.

Starmer, W. T., Lachance, M. A., Phaff, H. J., and Heed, W. B.
(1990) The biogeography of yeasts associated with decaying cactus tissue in North America, the Caribbean, and Northern Venezuela. Evol. Biol., 24, 253-296.

Suehiro, S. (1963) Studies on marine yeasts. III. Yeasts isolated from the mud of tide land. Sci. Bull. Fac. Agric. Kyushu Univ., 20, 223-227.

van Uden, N. (1967) Occurrence and origin of yeasts in estuaries. In Estuaries, ed. by Lauf, G. H., Am. Assoc. Adv. Sci., Washington, D.C., pp. 306-310.

Volz, P. A., Jerger, D. E., Worzburg, A. J., and Hiser, J. L. (1974) A preliminary survey of yeasts isolated from marine habitats at Abaco Island, the Bahamas. Mycopathol. Mycol. Appl., 54, 313-331. 